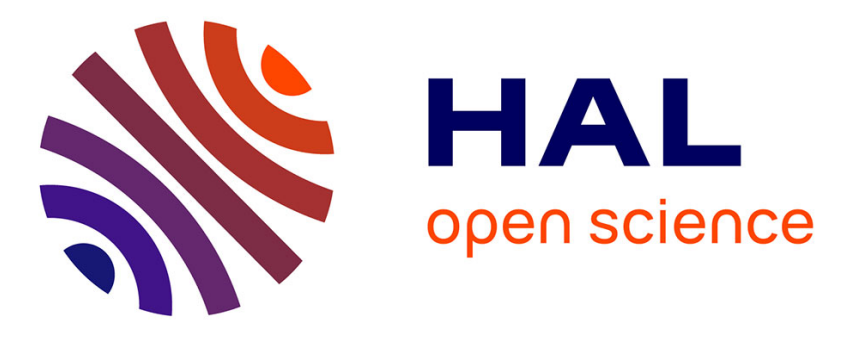

\title{
Structural and catalytic properties of the D-3-hydroxybutyrate dehydrogenase from Pseudomonas aeruginosa.
}

\author{
Driss Mountassif, Pierre Andreoletti, Mustapha Cherkaoui-Malki, Norbert \\ Latruffe, M'Hammed Saïd El Kebbaj
}

\section{To cite this version:}

Driss Mountassif, Pierre Andreoletti, Mustapha Cherkaoui-Malki, Norbert Latruffe, M'Hammed Saïd El Kebbaj. Structural and catalytic properties of the D-3-hydroxybutyrate dehydrogenase from Pseudomonas aeruginosa.: Bacterial D-3-hydroxybutyrate dehydrogenase.. Current Microbiology, 2010, 61 (1), pp.7-12. 10.1007/s00284-009-9568-7 . hal-00514502

\section{HAL Id: hal-00514502 \\ https://hal.science/hal-00514502}

Submitted on 2 Sep 2010

HAL is a multi-disciplinary open access archive for the deposit and dissemination of scientific research documents, whether they are published or not. The documents may come from teaching and research institutions in France or abroad, or from public or private research centers.
L'archive ouverte pluridisciplinaire HAL, est destinée au dépôt et à la diffusion de documents scientifiques de niveau recherche, publiés ou non, émanant des établissements d'enseignement et de recherche français ou étrangers, des laboratoires publics ou privés. 


\title{
Structural and catalytic properties of the D-3-hydroxybutyrate dehydrogenase from
}

\section{Pseudomonas aeruginosa}

\section{Driss Mountassif ${ }^{1,2}$, Pierre Andreoletti ${ }^{1}$, Mustapha Cherkaoui-Malki ${ }^{1}$, Norbert Latruffe ${ }^{1}$ *,} M'hammed Saïd El Kebbaj'

${ }^{1}$ INSERM U866; Université de Bourgogne; LBMC (Biochimie Métabolique et Nutritionnelle), Faculté des Sciences, 6 Bd Gabriel, 21000 Dijon cedex, France.

${ }^{2}$ Laboratoire de Biochimie et Biologie Moléculaire, Université Hassan II - Aïn Chock, Faculté des Sciences Aïn Chock, km 8 route d'El Jadida BP. 5366, Mâarif, Casablanca, Morocco.

\begin{abstract}
To put forward BDH from Pseudomonas aeruginosa enzymatic properties we report a two-step purification of $\mathrm{BDH}$, its gene sequencing allowing the investigation of its structural properties.

Purification of BDH was achieved, using ammonium sulfate fractionation and Blue Sepharose CL-6B affinity chromatography. SDS-PAGE analysis reveals a MM of $29 \mathrm{kDa}$, whereas the native enzyme showed a MM of $120 \mathrm{kDa}$ suggesting a homotetrameric structure. BDH encoding gene sequence shows a nucleotide open reading frame sequence of $771 \mathrm{pb}$ encoding a 265 amino acid residues polypeptide chain.

The modelling analysis of the three dimensional structure fits with the importance of amino acids in the catalysis reaction especially a strictly conserved tetrad. Amino-acid residues in interaction with the coenzyme $\mathrm{NAD}^{+}$were also identified.

* Corresponding author. E.mail address: Latruffe@u-bourgogne.fr
\end{abstract}

Running title: Bacterial D-3-hydroxybutyrate dehydrogenase.

\section{Keywords}

D-3-hydroxybutyrate dehydrogenase, Pseudomonas aeruginosa, quick purification, characterization.

\section{Introduction}

Pseudomonas aeruginosa is a gram negative bacterium and an important causative agent of nosocomial infections, particularly in intensive-care units [1] is a metabolically versatile micro-organism. While Pseudomonas aeruginosa is lactose negative, the NAD+-dependent D-3-Hydroxybutyrate 
dehydrogenase (BDH: EC 1.1.1.30) plays a key role in the redox balance and in the energetic metabolism by converting 3-hydroxybutyrate to acetoacetate. Interestingly, many bacteria synthesize and accumulate poly (3-hydroxybutyrate) (PHB) as intracellular carbon storage when the availability of nitrogen, phosphorus or oxygen in the environment is restricted. In PHB-accumulating bacteria, intracellular PHB is an electron sink in some bacteria $[2,3]$. The cell-accumulated PHB is degraded by PHB depolymerase to produce D-3hydroxybutyrate. During $\mathrm{BOH}$ oxidation, $\mathrm{NADH}$ is produced as an electron carrier to provide electrons to the plasma membrane located respiratory chain. On the other hand, eukaryotic BDH is an inner mitochondrial membrane bound enzyme, associated to the NAD+ linked electron transport chain [4]. As a very unique property, the catalytic activity of the enzyme is lecithin-dependent [5]. In contrast to mammalian, bacterium BDH is a cytosolic enzyme, where its activity is independent of the membrane phospholipids.

In order to characterize BDH from $P$. aeruginosa, we purified this enzyme by establishing a new purification technique. Indeed, previous methods used to purify bacterial BDH were time consuming, i.e. from Rhodopseudomonas spheroides [6] ; from Paracoccus denitrificans [7] or from Acidovorax sp [8]. Our method is based on two quick steps: ammonium sulfate fractionation and Blue Sepharose affinity chromatography. On the other hand, the BDH encoding gene has been cloned, sequenced and modellised. The computing analysis of the three dimensional structure fits with the importance of amino acids in the catalysis reaction especially a strictly conserved tetrad. Amino-acid residues in interaction with the coenzyme $\mathrm{NAD}^{+}$were also identified.

\section{Materials and methods}

\section{- Microorganisms and growth conditions.}

Bacterium Pseudomonas aeruginosa, strain PAO1 (Pasteur Institute, Casablanca, Morocco) was grown aerobically at $37^{\circ} \mathrm{C}$ without exceeding the exponential phase in nutrient broth (Topley House, Bury, UK). The exponential phase was determined spectrophotometrically at $600 \mathrm{~nm}$. The culture was inoculated with $1 \%(\mathrm{v} / \mathrm{v})$ overnight preculture in the same medium. 


\section{- Crude extract preparation.}

Bacterial culture (5 l) was harvested by centrifugation at $2500 \mathrm{~g}$ for $10 \mathrm{~min}$, washed three times with 50 $\mathrm{mM}$ potassium phosphate buffer ( $\mathrm{pH}$ 7.5), and suspended in the same buffer containing $2 \mathrm{mM}$ EDTA and 1 mM DTT (buffer A). Cells were disrupted at $4^{\circ} \mathrm{C}$ by sonication $(30 \mathrm{~s}, 90 \%$ output, $12 \mathrm{x})$ using a Bandelin Sonopuls sonifier. Cellular debris and unbroken cells were removed by centrifugation at $2500 \mathrm{~g}$ for $45 \mathrm{~min}$ at $4^{\circ} \mathrm{C}$. The supernatant obtained constituted the crude bacterial extract (soluble protein fraction).

\section{- Two steps - BDH purification.}

Ammonium sulfate fractionation(1) and Blue Sepharose CL-6B chromatography(2) .

(1) The crude extract of $P$. aeruginosa was subjected to protein precipitation in the $27-42 \%$ saturation range of ammonium sulfate at $4^{\circ} \mathrm{C}$ (buffer B) from buffer A containing ammonium sulfate at $50 \%$ saturation. The final pellet was dissolved in a minimal volume of buffer A. The protein solution was dialyzed overnight against 51 of the same buffer. (2) The dialyzed enzyme preparation was applied to a Blue Sepharose CL-6B column equilibrated with two bed volumes of buffer A at $4^{\circ} \mathrm{C}$. The column was washed with three bed volumes of buffer A. Finally, the enzyme was eluted with buffer A containing the coenzyme at $0.1 \mathrm{mM}$ $\mathrm{NAD}^{+}$at a flow rate of $6 \mathrm{ml} / \mathrm{h}$. Active fractions were collected and conserved in $50 \%(\mathrm{v} / \mathrm{v})$ glycerol at $-20^{\circ} \mathrm{C}$ until use. Protein content was measured according to the Bradford procedure, using bovine serum albumin (BSA) as standard [9].

\section{- Biochemical characterization of the BDH.}

\section{BDH activity, enzymatic parameters, optimal $\mathrm{pH}$ and temperature dependency.}

$\mathrm{BDH}$ activity, followed at $37^{\circ} \mathrm{C}$ by monitoring NADH production at $340 \mathrm{~nm}\left(\varepsilon=6.22 \times 10^{3} \mathrm{M}^{-1} \mathrm{~cm}^{-1}\right)$ and kinetic parameters were currently obtained as in [10]. Michaelis constants $\left(\mathrm{K}_{\mathrm{m}}\right)$, dissociation constants $\left(\mathrm{K}_{\mathrm{D}}\right)$ and maximal velocity for the oxidation of $\mathrm{BOH}$ and the reduction of $\mathrm{NAD}^{+}$were obtained by mathematical analysis following Cleland [11]. The effect of $\mathrm{pH}$ on $\mathrm{BDH}$ activity was studied in range from 
pH 4 to $\mathrm{pH} 10$ using a mixture of different buffers (Tris, Mes, Hepes, potassium phosphate and sodium acetate). Thermal activation and denaturation processes were followed as described in [10].

\section{Non-denaturing and denaturing polyacrylamide gel electrophoresis.}

To determine the native molecular weight of the purified BDH, non-denaturing polyacrylamide gel electrophoresis was carried out according to the method [12]. The separating gels $(6,8,10$ and $12 \%$ polyacrylamide) were buffered with $1.5 \mathrm{M}$ Tris- $\mathrm{HCl}(\mathrm{pH} 8.8)$. The running buffer was composed of $25 \mathrm{mM}$ Tris and $320 \mathrm{mM}$ glycine $\left(\mathrm{pH}\right.$ 8.6). All experiments were done at $4^{\circ} \mathrm{C}$. The electrophoresis running conditions, staining and destaining were as described for SDS-PAGE. The relative molecular weight of the native purified BDH was estimated using native molecular weight markers (Sigma). The apparent subunit molecular weight was determined by measuring relative mobilities in denaturation conditions unsing sodium dodecyl sulfate polyacrylamide gel electrophoresis (SDS-PAGE) performed as described by Laemmli [13] on one-dimensional $12 \%$ polyacrylamide slab gels containing $0.1 \%$ SDS and by comparing with the prestained SDS-PAGE molecular weight standards (Sigma).

\section{Western-blotting.}

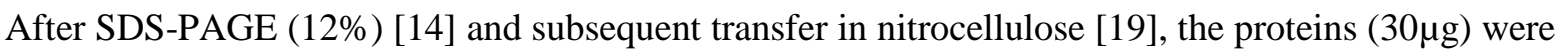
exposed to $1 / 100$ dilution of rabbit monospecific polyclonal anti-BDH antibody raised against purified rat liver BDH [15] and detected with the secondary antibody of anti-rabbit, IgG peroxidase conjugate (diluted to 1/2500) (Promega).

\section{- PCR and sequencing of the BDH cDNA clone from P. aeruginosa.}

DNA was extracted from Pseudomonas aeruginosa using Wizard Genomic Kit. An aliquot from the obtained DNA $(1 \mu \mathrm{l})$ was used in a subsequent polymerase chain reaction (PCR) using 1.25 U of GoTaq DNA polymerase (Promega), $0.04 \mu \mathrm{M}$ of forward (5'-GATGACCCTGAAAGGCAAGACC-3') and reverse primer (5'-CTACTGCGCCACCAGCC-3'). PCR conditions were 35 cycles of $92^{\circ} \mathrm{C}$ for $30 \mathrm{sec}, 51^{\circ} \mathrm{C}$ for 30 sec and $72^{\circ} \mathrm{C}$ for $1 \mathrm{~min}$. The primers used were obtained from the alignment between the sequences of BDH of 5 Pseudomonas strains (Pseudomonas aeruginosa, Pseudomonas fragi, Pseudomonas entomophila, 
Pseudomonas fluorescens, and Pseudomonas putida). The PCR product was purified using QIAEX II Kit (Qiagen) and subcloned into the pGEM-T vector system (Promega). Then the nucleotide sequence was determined after sequencing independently of the available genome sequence of Pseudomonas aeruginosa PAO1 on both strands using universal primers T7 and SP6 (MWG Biotech, Germany) in agreement with the NCBI accession n AAG05391.

\section{Results and discussion}

\section{Purification of soluble BDH from Pseudomonas aeruginosa.}

The BDH was purified to electrophoretic homogeneity from $P$. aeruginosa extract by ammonium sulfate fractionation $(27-42 \%)$, followed by the Blue Sepharose CL-6B chromatography. All steps were carried out at $4^{\circ} \mathrm{C}$. Table 1 summarizes a representative purification protocol. The SDS-PAGE analysis of the different fractions obtained during this purification procedure showed a progressive enrichment in $29 \mathrm{kDa}$ protein (Figure 1A). Only this protein band, having the same size than the BDH subunit, was seen in the electrophoretically homogeneous final enzyme preparation (Figure 1A, line 3).

After initial immunodetection tests of BDH from $P$. aeruginosa using a polyclonal rabbit antibody raised against rat liver $\mathrm{BDH}$ [20], we have produced specific rabbit polyclonal antibodies using purified BDH from $P$. aeruginosa as immunogen [10]. These antibodies selectively recognize a single immunoreactive band in both crude extracts and purified preparations. Figure 1B, shows that the relative molecular mass of the detected protein $(29 \mathrm{kDa})$ is the expected one for the $\mathrm{BDH}$ monomer in denaturing conditions (Figure 1B).

\section{Properties of the purified BDH from $P$. aeruginosa}

The molecular weight obtained for the purified BDH from P. aeruginosa corresponds to $29 \mathrm{kDa}$ (not shown), while non-denaturing PAGE showed that the native molecular weight of the P. eruginosa protein was approximately $120 \mathrm{kDa}$ (not shown), size in agreement with a homotetrameric structure of this BDH. The BDH kinetic parameters of the purified BDH from P. eruginosa were determined. The results obtained 
show a value of $15.5 \mathrm{U} / \mathrm{mg}$ for $\mathrm{V}_{\max }, 0.16 \mathrm{mM}, 3.7 \mathrm{mM}$ and $0.6 \mathrm{mM}$ for $\mathrm{K}_{\mathrm{m}} \mathrm{NAD}^{+}, \mathrm{K}_{\mathrm{m}} \mathrm{BOH}$ and $\mathrm{K}_{\mathrm{D}} \mathrm{NAD}^{+}$ respectively. Similar values have been obtained for other BDH sources. The effect of temperature on the $\mathrm{BDH}$ activity shows that the optimal temperature for the $\mathrm{BDH}$ activity was $40^{\circ} \mathrm{C}$ (not shown). A different optimum temperature $\left(55^{\circ} \mathrm{C}\right)$ was found for $\mathrm{BDH}$ from Acidovorax [8]. In agreement with the soluble type of this BDH, Arrhenius-plot is linear (not shown) and doesn't show any break as it is the case for the lipid dependent and membrane bound eukaryotic $\mathrm{BDH}[10]$. The optimal $\mathrm{pH}$ of the $\mathrm{BDH}$ activity is equal to 8 (not shown). Similar results were found for other bacteria; Acidovorax, Rhodospirillum rubrum and Rhodopseudomonas spheroides [8] and for rat [10].

\section{cDNA sequencing and protein structural modelling}

In order to clone the gene encoding bacterium BDH from $P$. aeruginosa, primers were designed following the alignment of $5 \mathrm{BDH}$ sequences from Pseudomonas strains (Pseudomonas aeruginosa, Pseudomonas fragi, Pseudomonas entomophila, Pseudomonas fluorescens, Pseudomonas putida). The designed primary sequence encode $\mathrm{N}$ - and $\mathrm{C}$-termini BDH polypeptide. PCR amplification revealed a single DNA fragment with the expected size (771 pb) (not shown). Using BioEdit program [17], the mutiple alignement of Pseudomonas aeruginosa BDH amino-acid sequence with several other species reveals between 50 and $74 \%$ of identity between different bacterial BDH sequences. In comparison with human, the percentage of identity falls to $15.9 \%$. Sequences analysis also shows the existence of 32 identical amino acids along the polypeptide chain in comparison between all BDH sequences (bacteria and human). The analysis of these amino acids using the data related to the crystal structure of the BDH of Pseudomonas fragi (the only one so far crystallized and modelised BDH [18]) indicates that these amino acids were localized next to the BDH active site (not shown) and both structures are almost identical (not shown).

In conclusion, the BDH single chain molecular weight of $29 \mathrm{kDa}$ from Pseudomonas aeruginosa is similar from the ones obtained for BDH from Acidovorax (27 kDa) and Rhodospirillum rubrum (28 kDa) [8]. However, for eukaryotic BDH, the molecular weight was slightly higher, i.e. $31.5 \mathrm{kDa}$ for eukaryotic BDH

[16]. In contrast, like $\mathrm{BDH}$ from other bacterial source [8] the quaternary structure of $\mathrm{BDH}$ from 
Pseudomonas aeruginosa corresponds to a tetrameric form. The large divergence between mammalian and bacterial $\mathrm{BDH}$ sequences is in part due to the presence of $\mathrm{N}$-terminus and $\mathrm{C}$-terminus extensions in the mammalian enzyme and in the other part in architectures differences of both enzymes especially since the mammalian $\mathrm{BDH}$ is mitochondrially membrane bound while the bacterial one is cytosoluble (highlighted in red in human BDH sequence in figure 2). Modelling analysis done using spdbv logiciel and Swiss Model Server fits with the importance of amino acids in the catalysis reaction especially the strictly conserved tetrad: Asn114, Ser142, Tyr155 and Lys159 (not shown). On the other hand, Ito [18] reported that the adenine of $\mathrm{NAD}^{+}$is accommodated in the BDH hydrophobic pocket comprising Gly11, Leu64, Ala90, Ile93 and Leu113. All of these residues were found in all compared BDH sequences (Figure 2).

This work puts forward a new and two-steps simple and inexpensive procedure to quickly purify the BDH from Pseudomonas aeruginosa in a native and homotetrameric form and achieved between one to one and half day. The sequence of this gene encoding gene contains highly conserved tetrad of amino-acids. The exact role of this enzyme in the energetic balance of Pseudomonas aeruginosa remains to be understood.

\section{Acknowledgements}

Supported by the Regional Council of Burgundy and IFR n. 100, the Programme Thématique d'Appui à la Recherche Scientifique-Morocco, Biologie No.134, and the AI franco-marocaine MA/05/134.

\section{References}

1. Trautmann, M., Lepper, P.M., Haller, M. (2005). Ecology of Pseudomonas aeruginosa in the intensive care unit and the evolving role of water outlets as a reservoir of the organism. Am J Infect Control 33: $41-49$.

2. Dawes, E.A. and Senior, P.J. (1973). The role and regulation of energy reserve polymers in microorganisms. Adv. Microb. Physiol., 10: 135-266.

3. Anderson, A.J. and Dawes, E.A. (1990). Occurrence, metabolism, metabolic role, and industrial uses of bacterial polyhydroxyalkanoates. Microbiol. Rev., 54: 450-472. 
4. Wise, J.B., Lehninger, A.L. (1962). The stability of mitochondrial D-3-hydroxybutyric dehydrogenase and its relationships to the respiratory chain. J. Biol. Chem. 237: 1363-1670.

5. Gazzotti, P., Bock, H.G.O., Fleischer, S. (1974). Role of lecithin in D-3-hydroxybutyrate dehydrogenase function, Biochem. Biophys. Res. Commun. 58: 309-315.

6. Bergmeyer, H.U., Gawehn, K., Klotzsch, H., Krebs, H.A., Williamson, D.H. (1967). Purification and properties of crystalline 3-hydroxybutyrate dehydrogenase from Rhodopseudomonas spheroides. Biochem J., 102: 423-431.

7. Matyskova, I., Kovar, J., Racek P. (1985). Purification and properties of D-3-hydroxybutyrate dehydrogenase from Paracoccus denitrificanss. Biochimica et Biophysica Acta 839: 300-307.

8. Takanashi, M., Shibahara, T., Shiraki, M., Saito, T. (2004). Biochemical and Genetic Characterization of a D-3-Hydroxybutyrate dehydrogenase from Acidovorax sp. Strain SA1. J Biosci Bioeng 1: 78-81.

9. Bradford, M. (1976). A rapid and sensitive method for the quantitation of microgram quantities of protein utilizing the principle of protein dye binding, Anal. Biochem., 72: 248-254.

10. Mountassif, D., Andreoletti P., El Kebbaj Z, Moutaouakki A., Mustapha Cherkaoui-Malki M., Latruffe N., El Kebbaj MS. (2008). Immunoaffinity purification and characterization of mitochondrial membrane-bound D-3-hydroxybutyrate dehydrogenase from Jaculus orientalis. BMC Biochem 9 (1): e26.

11. Cleland, W.W. (1963). The Kinetics of enzymes catalysed reaction with two or more substrates or products, Nomenclature and rate equations, Biochim. Biophys. Acta 67: 104-137.

12. Hedrick, J.L., Smith, A.J. (1968). Size and charge isomer separation and estimation of molecular weights of proteins by disc gel electrophoresis. Arch. Biochem. Biophys., 126: 155-164.

13. Laemmli, U.K. (1970). Cleavage of structural proteins during the assembly of the head of bacteriophage T4. Nature 227: 4668-4673.

14. Towbin, H., Stahelin, T., Gordon, J. (1992). Electrophoretic transfer of proteins from polyacrylamide gels to nitrocel procedure and applications. Biotechnology 24: 145-149.

15. Coquard, C, Adami, P., Cherkaoui Malki, M., Fellmann, D., Latruffe, N. (1987). Immunological study of the tissue expression of D-3-hydroxybutyrate dehydrogenase, a ketone body converting enzyme. Biol. 
Cell, 181: 381-388.

16. Burnett, B.K., Khorana, H.G. (1985). A rapid and efficient procedure for the purification of mitochondrial D-3-hydroxybutyrate dehydrogenase. Biochim. Biophys. Acta 815: 51-56.

17. Hall, T.A. (1999). BioEdit: a user-friendly biological sequence alignment editor and analysis program for Windows 95/98/NT. Nucl. Acids. Symp. Ser. 41: 95-98.

18. Ito, K., Nakajima, Y., Ichihara, E., Ogawa, K., Katayama, N., Nakashima, K., Yoshimoto, T. (2005). D3-hydroxybutyrate dehydrogenase from Pseudomonas fragi: Molecular cloning of the enzyme gene and crystal structure of the enzyme J. Mol. Biol., 355: 722-733.

19. Thompson JD, Higgins DG, Gibson TJ. (1994). CLUSTAL W: improving the sensitivity of progressive multiple sequence alignment through sequence weighting, position-specific gap penalties and weight matrix choice. Nucleic Acids Res. 22: 4673-80.

\section{Legend of figure 1: BDH purification steps from Pseudomonas aeruginosa.}

Proteins $(40 \mu \mathrm{g})$ were resolved by SDS-PAGE and stained with Coomassie Brilliant Blue (a) or subjected to Western blot (b) using the purified polyclonal anti-BDH antibodies. Lanes $\mathrm{M}, 1,2,3,4$, and 5 respectively represent standard proteins, crude extract, 30-50\% ammonium sulphate fraction, phenyl-Sepharose fraction, affinity chromatography fraction, and immunoaffinity chromatography eluate pool (pure protein preparation). Bound antibody was located by immunoreaction combined with peroxidase conjugated goat anti-rabbit IgG. The arrow (b) indicates the band corresponding to the BDH subunit.

\section{Legend of figure 2: Alignment of BDH sequences}

Alignment of $\mathrm{BDH}$ sequences from different bacterial species and from human with Pseudomonas aeruginosa ( $P$. a.) was realized using Clustal [19]. Identical residues are highlighted in red and similar residues were shown in yellow. The high identity between bacterial sequences (from $50 \%$ to $74 \%$ ) is visible with the presence of red blocks of amino acids. On the contrary, the weak identity with the human BDH sequence is located on peculiar regions corresponding to amino acids of the active site and substrate binding pocket. 
Table 1 Purification steps of BDH from Pseudomonas aeruginosa

\begin{tabular}{lcccc}
\hline & $\begin{array}{l}\text { Total protein } \\
(\mathrm{mg})\end{array}$ & $\begin{array}{l}\text { Specific activity } \\
(\mu \mathrm{mol} / \mathrm{min} / \mathrm{mg} \text { of protein) }\end{array}$ & $\begin{array}{l}\text { Total activity } \\
(\mu \mathrm{mol} / \mathrm{min})\end{array}$ & $\begin{array}{l}\text { Purification } \\
\text { factor (fold) }\end{array}$ \\
\hline Crude extract & 4,600 & 0.22 & 1,012 & 1 \\
Ammonium sulfate $(27-42 \%)$ & $301^{*}$ & 0.82 & 246.8 & 3.7 \\
Sepharose-Blue & 6 & 11.2 & 67.2 & 50.9 \\
\hline
\end{tabular}

Typical experiments were reported from three independent trials

* The ammonium sulfate precipitation step allows the elimination of $94 \%$ of contaminating proteins from $P$. aeruginosa crude extracts. This value was calculated from the total protein amount subtracted from the amount of BDH (estimated from specific activities Sepharose-Blue chromatography step) 
A

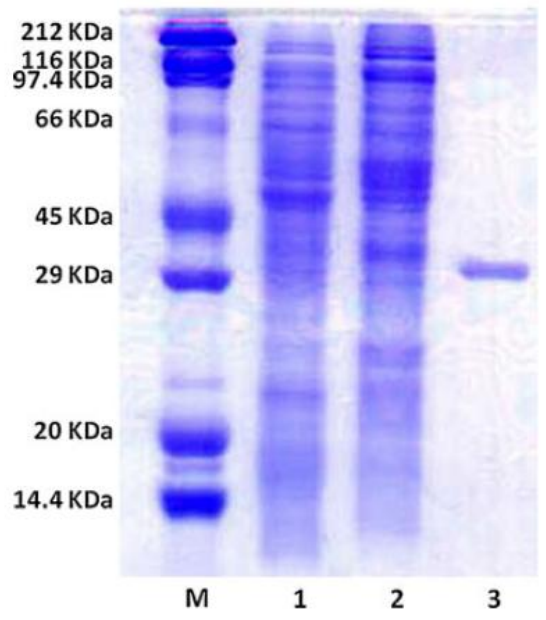

Fig. 1 BDH purification steps from Pseudomonas aeruginosa. Proteins were resolved by SDS-PAGE and stained with Coomassie Brilliant Blue (a) or subjected to Western blot (b) using the purified polyclonal anti-BDH antibodies. Lanes $\mathrm{M}, 1,2$, and 3, respectively, represent standard proteins, crude extract $(40 \mu \mathrm{g}), 27-42 \%$ ammonium
B

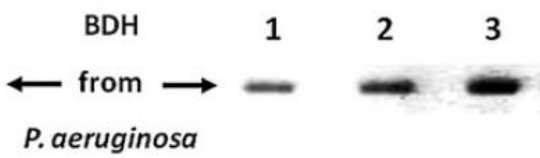

sulfate fraction $(40 \mu \mathrm{g})$, phenyl-Sepharose chromatography eluate pool ( $4 \mu \mathrm{g}$ of pure protein preparation). Bound antibody was located by immunoreaction combined with peroxidase conjugated goat anti-rabbit $\mathrm{IgG}$. The arrow indicates the band corresponding to the $\mathrm{BDH}$ subunit 


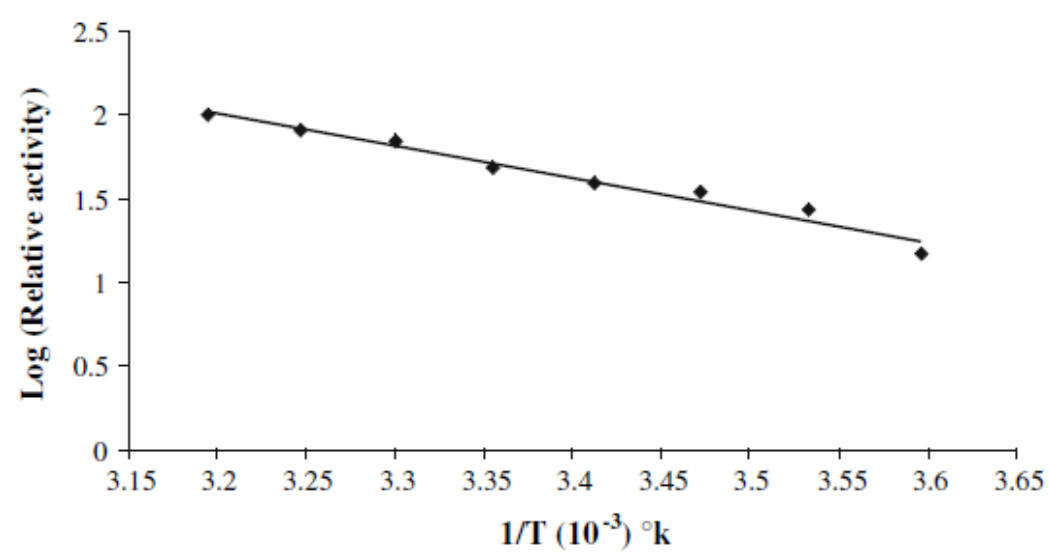

Fig. 2 Arrhenius plot of BDH. The plot was obtained by measuring the enzymatic activity using $10 \mu \mathrm{g}$ of the purified protein at various temperatures (from 5 to $40^{\circ} \mathrm{C}$ ). The values represent the mean of three independent assays 

Pseudomonas fragi

Pseudomonas entomophila pseudomonas fluorescens pseudomonas putida Rhodopseudomonas palustris Serratia proteanaculans Human

Pseudomonas aeruginosa Pseudomonas fragi

Pseudomonas entomophil pseudomonas fluorescens pseudomonas putida Rhodopseudomonas palustris Serratia proteamaculans Hunan

Pseudomonas aeruginosa Pseudomonas fragi Pseudomonas entomophil pseudomonas fluorescen pseudomonas putida preudonas putida Serratia proteamaculans Human

Pseudomonas aeruginosa Pseudomonas fragi

Pseudomonas ent omophil pseudomonas fluorescens pseudomonas putida

Rhodopseudomonas palustris Serratia proteanaculans Human

Fig. 3 Alignment of BDH sequences from different bacterial species and from human with Pseudomonas aeruginosa (P. a.) was realized using Clustal [21]. Identical residues are highlighted in red and similar residues were shown in yellow. The high identity between bacterial$$
190
$$

200

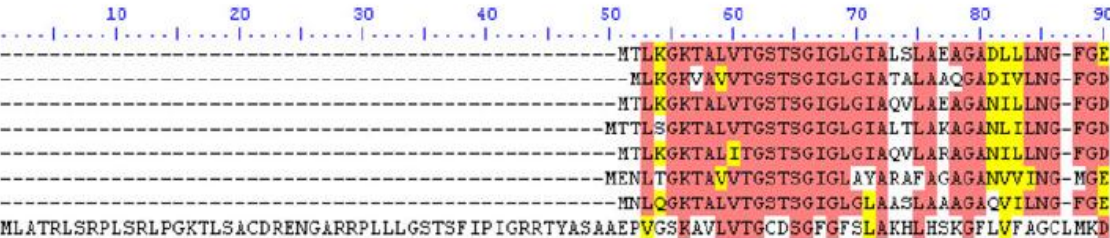

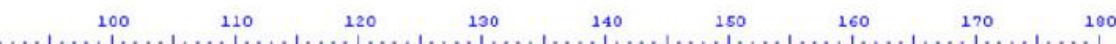
VD ARL $1 \ldots 1 \ldots 1 \ldots 1 \ldots 1 \ldots 1 \ldots 1 \ldots 1 \ldots 1 \ldots 1 \ldots 1 \ldots 1 \ldots 1 \ldots 1 \ldots 1 \ldots 1 \ldots 1 \ldots 1 \ldots 1 \ldots$

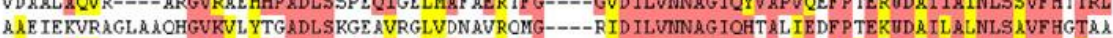

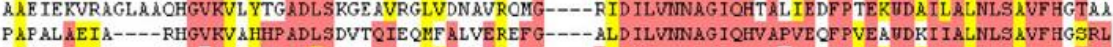
ASKVI AEVE----OF GGKVGHHP ADVSDP AQIAD WI Y Y AEREF G----GVD ILVINA G IQHV A AVE EF PVERUDS I I INLSSVF HSTR PAP AL AEVT---- QHGVKV AHHP ADL GDVAQIE ALFAF AE QTF G----CVD ILVINAG IQHVAPVECF PVESUDKI IALNLS AVFHGTRL AAD IERERAK IESDF GVKAVYSP ADMLKP AE IAENVALGETTFG----AVD I LVUNAG IQFVSP IE DF P IEKUDA I I INLSS AF HG IRI

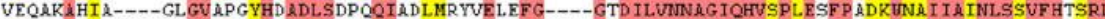
KGHDGVKE L DS--LNSDRL RTVQLNVCSSEEVE KVVE IVRSSL KD PEKGMWGLVINAGISTT GEVEFTSLETYKQV AEVNL WGTVRHTKS

210

220

230

240 250 $260 \quad 270$

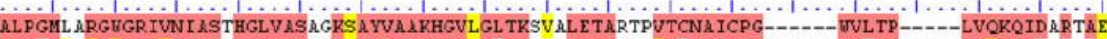

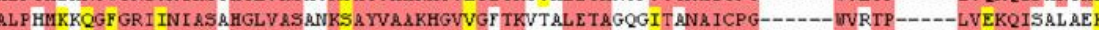

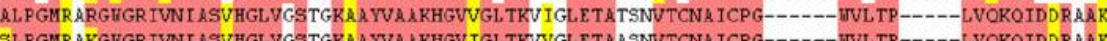
SLP GMRAKGUGR IVN I ASVHGLVGSTGRAA YVAAKHGV IGL TKVVGLETAASNVTCNA ICPG------WVLTP----LVQKQIDDRAA ALPGMRKRNIIGR IVN I ASVHGLVGSTGKA A TVRAKHGVVGL TKVVGLETAT GNVTCNA ICPG------WVL TP-----LVQKQIDERA.AK

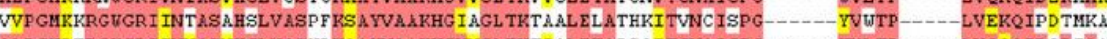

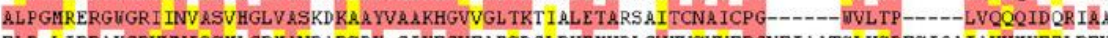

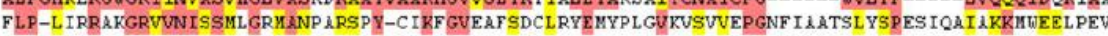

$$
\begin{array}{lllllll}
280 & 290 & 300 & 310 & 320 & 330 & 340
\end{array}
$$

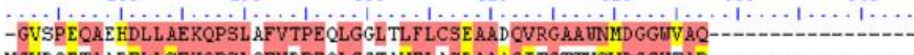
NGVDOETAAPELLSEROPSLOFVDPEOLGGTAUFL ASD MANITCTTVSVDCCUTAR--

-GGDPLQAOHDLL AEKQPSLAFVTPRHLGELVLF LCSE AGSOVRGAAUNVDGGLL

-GVDPOOAOHDLL AE KOPSL EFVTP A HLGELVLFLCSE AGSOVRG MRUNIDGGWL.

GVAPQQA QADLLAE KQPSLAFVTPËHLGELVLTLCSEAASQVRGAAUNVDGGUL

RNL TKE OV INDVL LL ROPTKOFVTSEOVAAL AL TLCGD DASOIT GANLSMD GGUTAA-

-GTDPQQARNDLLAEKQPSLEFVTPEQLGELALFLCSDAAVQVRGAANNMD GGULAQ

VRKYGKKYFDEKT AKYE TYCSSGSTD TSPVID AVTHAL TATTPYTRYHPMD YYWULRMOIMTL PG ISD MIYI

sequences (from 50 to $74 \%$ ) is visible with the presence of red blocks of amino acids. On the contrary, the weak identity with the human BDH sequence is located on peculiar regions corresponding to amino acids of the active site and substrate binding pocket. (Color figure online) 
Fig. 4 Modeling of BDH from Pseudomonas aeruginosa. Stick model showing the conserved residues (identical in blue and similar in yellow) interacting with $\mathrm{NAD}^{+}$(in red). The interactions between atoms were shown by green lines. (Color figure online)

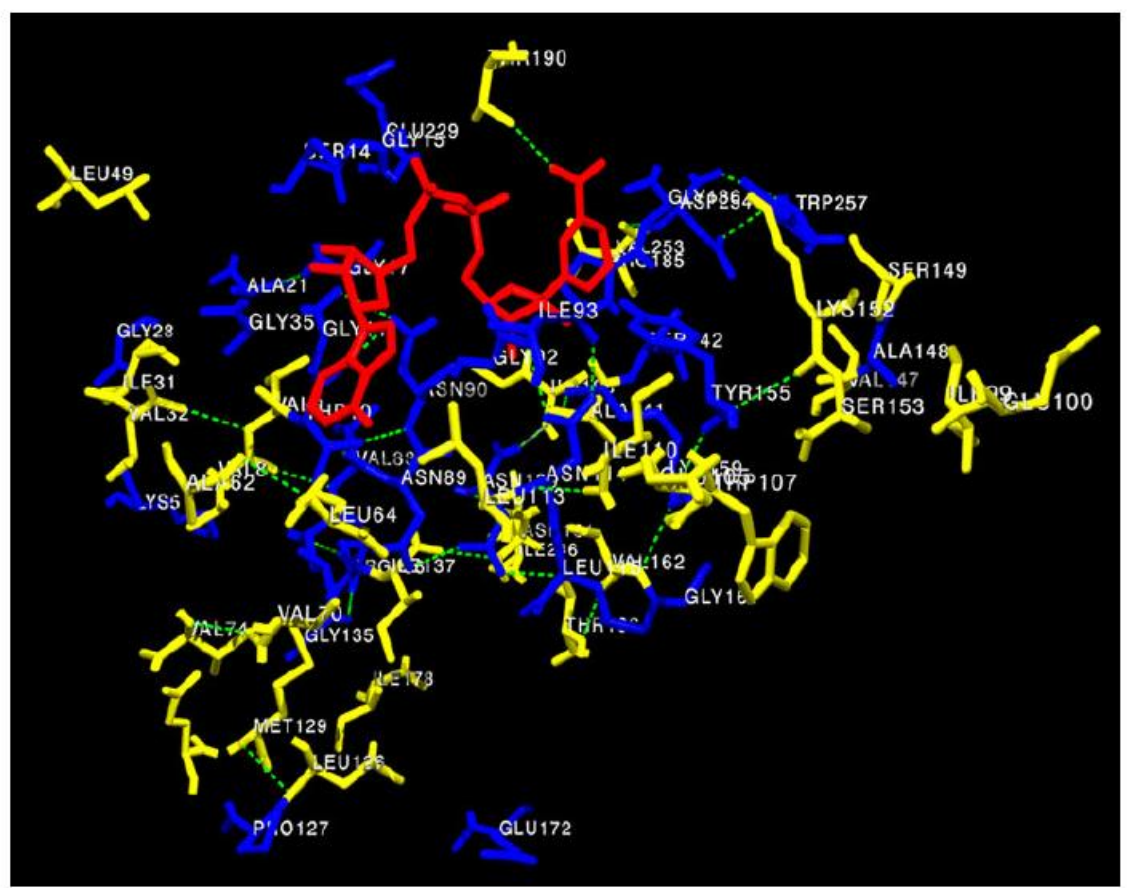

